\title{
Implementing a complex hospital innovation: Conceptual underpinnings, program design and implementation of a Complex Innovation in an International Multi-Site Hospital Trial
}

Karen Dryden-Palmer ( $\square$ karen.dryden-palmer@sickkids.ca )

University of Toronto

Whitney B. Berta

University of Toronto

Christopher S. Parshuram

University of Toronto

\section{Research Article}

Keywords: implementation design, knowledge translation, health care, innovation

Posted Date: February 14th, 2022

DOI: https://doi.org/10.21203/rs.3.rs-1257058/v1

License: @ (i) This work is licensed under a Creative Commons Attribution 4.0 International License. Read Full License 


\section{Abstract}

Background: Designing implementation programs that effectively integrate complex healthcare innovations is a fundamental aspect of knowledge translation. Good implementation design requires an active process. We describe a conceptually-grounded framework for the design of implementation programs for complex healthcare innovations and describe its implementation in pediatric hospital settings.

Methods: We articulate the grounding implementation model and define overarching goals and principles of the implementation program design. Our Phased Reciprocal Implementation Synergy Model (PRISM) for implementation informed the articulation of the seven design principles: phased implementation approach, enduser engagement, responsive design, intentional integration with existing team processes, customizable implementation interventions, attendance to social mechanisms of influence, and inclusion of processes that support both learning and unlearning processes. These were then operationalized into implementation program, activities and innovation-specific tools.

Results: The evidence informed and context responsive implementation program was applied to a complex, hospital wide implementation. Implementation interventions, education, communication and formative and summative evaluation tools were developed then customized for each participating hospital.

Conclusion: Theoretically grounded and locally contexted implementation approaches are feasible for the adoption and integration of complex hospital wide innovations. Attention to the fitting of an innovation to local practices, the setting, organizational culture and end-user preferences can be achieved while maintaining the fidelity of the innovation.

\section{Introduction}

Implementation programs should ideally result in adoption and sustainment of newly introduced innovations (14). Despite the significant investment of development time, research resources and patient collaboration involved in the creation of complex healthcare innovations, robust descriptions of effective implementation strategies for complex innovations are limited (5-9).

Challenges in effective implementation in healthcare can relate to the innovation, the end-users and the organizations in which implementation occurs (2). End-users with diverse clinical backgrounds, strongly held preexisting practices, and diverse practice realities may add complexity to standardized implementation approaches and derail adoption (10). Furthermore, complexity can arise from the innovation itself if cooperation/coordination of multiple end-users is required, if a series of actions or multiple steps are part of the desired behavioral change or when individual judgment for the innovation's application is necessary (11-16). Organizations may also differ in terms of approaches taken to instituting practice change adding opacity to designing best implementation approaches across multiple organizations (17).

Following the creation of a novel complex healthcare innovation, the Bedside Paediatric Early Warning System or BedsidePEWS, an EPOCH international cluster randomized control trial was organized. We identified this RCT as an opportunity to develop an evidence-informed approach to implementing this organizational-wide innovation that both standardized the essential components of the innovation and was responsive to the esoteric organizational contexts, resources and the priorities of the participating hospitals and teams $(18,19)$. 
In response to this challenge, we designed and applied a conceptually-grounded, evidence-based implementation program in order to facilitate the efficient adoption and sustainment of a complex, team-based hospital wide innovation, in differing contexts of pediatric acute hospital care (19-21).

Here we describe the conceptual model that grounds the implementation approach, the design elements for the implementation program, the rationale for each design choice, and how we operationalized these elements to support the implementation in this multisite trial.

\section{Background}

The design of implementation programs to support the adoption of complex healthcare innovations is far from simple. First, there is a limited evidence-base to inform specific design choices for implementation programs. Second, the process of implementation frequently involves allocation of significant time and resources to support the introduction, preparation, the activation and integration of complex healthcare innovations into their intended environments. Third, the process of implementation involves navigating complexity, reciprocal interactions and customization of the innovation to fit the context for its application. Further complexity can emerge during implementation as the innovation and implementation processes influence and shape the context. In the absence of empiric evidence, the use of a theoretically grounded approach seemed most appropriate to navigate these dynamic challenges.

Our review of the literature informing implementation in hospital organizations surfaced a lack of conceptual clarity, and limited appreciation of complexity and reciprocity in reporting implementation approaches. Early conceptualizations of knowledge adoption favored a linear perspective to knowledge translation and evidence adoption grounded on exposure, spread and individual level learning $(22,23)$. The assumption that access to evidence would logically lead to integration of the innovation into practice left questions as to how to best navigate, account for and optimize individual, team and organization factors to achieve and sustain the desired change $(7,24)$. This assumption fails to account for the impacts of complexity of the intervention, in the processes of implementation and the context $(20,25)$. Implementation approaches that acknowledge hospital systems are dynamic and will respond to new ideas in unpredictable ways and innovations are changed and manipulated at the point of application are needed.

Our review of the literature demonstrated that conceptualizations and models to address the complexities of implementation were lacking. We developed the Phased Reciprocal Implementation Synergy Model (PRISM) in response to these limitations. Originally published as the 'Tunnel Model of Implementation', PRISM is grounded in the implementation design literature (2). PRISM acknowledges; the impact of pre-existing processes embedded in the implementing organization; the inter-relatedness and bi-directional effects between the innovation, implementation processes and the context; the potential for multiple different micro contexts within a given organization; the necessity to develop and continuously refine and revise processes for implementation; and the need to actively facilitate learning/unlearning across the continuum of implementation $(2,26)$. Figure 1 illustrates the PRISM model and interactions between context, the innovation and implementation processes.

Consideration of the potential interaction between context, complexity, process and the innovation are key in planning for non-linear, dynamic and potentially unpredictable impacts of the innovation in the varied practices spaces where implementation is planned (27). The PRISM framework facilitates internal consistency of the 
innovation and implementation program activities and enables the integration of best available evidence guiding implementation.

\section{Methods}

\section{Implementation Program Structure:}

A phased approach structures implementation and optimizes efficiency in a dynamic environment $(13,28)$. Phased implementation also permits thoughtful iterative and cumulative evaluations of smaller scale implementations in the micro-contexts across a given organization, and provides a means for the end-users to teach and lead one another from within. These intentional phases provide a structure to implementation progression, afford opportunities for routine and timely communication across the organization and align the activities and goals of each phase.

Based on the Observed Knowledge Translation Application Process, PRISM structures implementation activities in phases of Preparation, Introduction, Activation and Integration (figure 1) $(2,20)$. Following the organizational decision to adopt implementation activity begins with phase 1, organizational Preparation focused on implementation planning and customization, moving next to the Introduction phase focused on end-user's exposer to the innovation. Following the Introduction phase, the Activation phase centers of the novel application of the innovation in the desired setting. Finally, the Integration phase address solidifying the innovation as usual practice and setting up for sustainment. Sustainment planning is informed by Argote's reservoirs of organizational knowledge and local teams are encourage to target as many reservoirs as possible to support the innovation after the external influences of active implementation programming end $(29,30)$. Establishing sustainment activities and the gradual transition to local team leadership for ongoing ownership of the new practice(s) marks the end of the implementation program.

The phases reflect expectations of stepwise knowledge transfer across a complex organization and active support of internalization and normalization of the new practice behaviours. Target dates for each phase are determined collaboratively between the local and external implementation teams. Local implementers play a central role in planning implementation interventions ensuring implementation activities complement other planned hospital activities, integrate the plan with organizational priorities, and help inform and engage other hospital leaders in implementation decision-making and problem solving. There are specific activities aligned within each phase as well as feature of the implementation design that bridge across multiple phases.

\section{PRISM phases:}

\section{Preparation phase}

Implementation leadership is established in the Preparation phase and carries on throughout the entire program. Leadership structure for implementation utilizes a collaborative two-team framework including (i) an external team of content experts and (ii) an internal/local team of organizational experts. External innovation experts and local organizational experts use an intentional organizing hierarchy to facilitate knowledge transfer. This approach provides external stewardship of the innovation and support of the reciprocal changes occurring across implementation as compared to designs focused on education only or transfer of implementation materials/training to the target user group. The external content experts serve as knowledge reservoirs about the 
innovation, bringing broad implementation experience and actively facilitate solution building for local challenges over the course of implementation. The advantages of maintaining an external expert group include recognition and enabling of synergies across groups within a given organization, helping facilitate customization of the innovation, ensuring innovation fidelity within each implementation, providing consistency across different implementations, and enabling of shared learning between organizations.

Local organizational experts comprise the on the ground implementation leadership. The purpose of establishing a local core implementation team in the Preparation phase is to bring local system and resource knowledge to implementation planning and to capitalize on existing relationships and connections within the organization. The required characteristics, skill sets and scope for local team members is determined by the implementing organization. The core implementation team within each organization interacts with other teams within their setting to share and external experts to gather information that facilitates implementation 'fit' thus improving the matching of the innovation to context, local processes and resources.

Together the external and local implementation teams build the implementation roles for the organization during this initial phase. The external team determines role and scope while the local leadership team determine how roles will operationalize within the existing organizational structure and who would best fill these roles. Table 1 describes the four-implementation roles, responsibilities associated organizational positions, the phases where each role is most active and areas where the role is influential. Together the external and local implementation teams, in collaboration with primary implementers, determine the specific implementation activities for the organization. 
Table 1

Implementation Roles

\begin{tabular}{|c|c|c|c|c|}
\hline Role & $\begin{array}{l}\text { Implementation } \\
\text { Responsibilities }\end{array}$ & $\begin{array}{l}\text { Associated } \\
\text { organizational role(s) }\end{array}$ & PRISM phase & Area of influence \\
\hline $\begin{array}{l}\text { Primary } \\
\text { implementation } \\
\text { planners }\end{array}$ & $\begin{array}{l}\text { Organizational level } \\
\text { decision-making and } \\
\text { stewardship of } \\
\text { implementation } \\
\text { processes } \\
\text { Oversite of } \\
\text { customization of } \\
\text { tools/materials/timing } \\
\text { Remove } \\
\text { organizational level } \\
\text { barriers to } \\
\text { optimization the fit of } \\
\text { the innovation and the } \\
\text { implementation } \\
\text { interventions } \\
\text { Design education, } \\
\text { select marketing and } \\
\text { dissemination } \\
\text { activities } \\
\text { Oversight of material } \\
\text { production and } \\
\text { distribution, respond to } \\
\text { challenges emerging } \\
\text { during implementation } \\
\text { Design sustainment } \\
\text { activities }\end{array}$ & $\begin{array}{l}\text { Key organizational } \\
\text { decision makers } \\
\text { Local unit leaders } \\
\text { Research and } \\
\text { education } \\
\text { leaders/experts }\end{array}$ & $\begin{array}{l}\text { Preparation } \\
\text { Introduction } \\
\text { Activation } \\
\text { Integration }\end{array}$ & $\begin{array}{l}\text { Organizational- } \\
\text { level } \\
\text { Resource } \\
\text { allocation } \\
\text { Project oversite }\end{array}$ \\
\hline $\begin{array}{l}\text { Secondary } \\
\text { implementation } \\
\text { operators }\end{array}$ & $\begin{array}{l}\text { Deliver } \\
\text { implementation } \\
\text { interventions } \\
\text { Monitor } \\
\text { implementation } \\
\text { activities/impacts and } \\
\text { feedback to } \\
\text { implementation teams } \\
\text { Participate in ongoing } \\
\text { customization and } \\
\text { integration of } \\
\text { innovation } \\
\text { Organizational } \\
\text { dissemination } \\
\text { information about the } \\
\text { innovation }\end{array}$ & $\begin{array}{l}\text { Organizational } \\
\text { educators } \\
\text { Unit leaders within } \\
\text { organization } \\
\text { Selected end-users } \\
\text { identified by the local } \\
\text { primary team as } \\
\text { recognized as } \\
\text { influencers in the end } \\
\text { user communities }\end{array}$ & $\begin{array}{l}\text { Introduction } \\
\text { Activation } \\
\text { Integration }\end{array}$ & $\begin{array}{l}\text { Team and } \\
\text { individual level } \\
\text { Practice advisors } \\
\text { Role models } \\
\text { Early Adopters }\end{array}$ \\
\hline
\end{tabular}




\begin{tabular}{|c|c|c|c|c|}
\hline Role & $\begin{array}{l}\text { Implementation } \\
\text { Responsibilities }\end{array}$ & $\begin{array}{l}\text { Associated } \\
\text { organizational role(s) }\end{array}$ & PRISM phase & Area of influence \\
\hline \multirow{3}{*}{$\begin{array}{l}\text { Tertiary } \\
\text { implementation } \\
\text { facilitators }\end{array}$} & \multirow{2}{*}{$\begin{array}{l}\text { Disseminate } \\
\text { information about the } \\
\text { innovation to } \\
\text { individuals and teams }\end{array}$} & \multirow{2}{*}{$\begin{array}{l}\text { Frontline staff who are } \\
\text { positioned to } \\
\text { facilitated } \\
\text { use/application of the } \\
\text { innovation }\end{array}$} & $\begin{array}{l}\text { Champions, } \\
\text { Educators }\end{array}$ & $\begin{array}{l}\text { Team and peer } \\
\text { level }\end{array}$ \\
\hline & & & \multirow[t]{2}{*}{ Team leaders } & \multirow{2}{*}{$\begin{array}{l}\text { Utilize } \\
\text { established tools } \\
\text { content without } \\
\text { altering content, } \\
\text { structure or intent }\end{array}$} \\
\hline & $\begin{array}{l}\text { Support integration of } \\
\text { the innovation at point } \\
\text { of care }\end{array}$ & $\begin{array}{l}\text { May also be end-users } \\
\text { of the innovation }\end{array}$ & & \\
\hline \multirow[t]{2}{*}{ End-users } & $\begin{array}{l}\text { Participate in } \\
\text { Implementation } \\
\text { activities including }\end{array}$ & $\begin{array}{l}\text { Any team member } \\
\text { who will use the } \\
\text { innovation }\end{array}$ & \multirow{2}{*}{$\begin{array}{l}\text { Multidisciplinary } \\
\text { professionals } \\
\text { across all } \\
\text { applicable areas } \\
\text { of the } \\
\text { organization }\end{array}$} & \multirow{2}{*}{$\begin{array}{l}\text { Involvement in } \\
\text { the preparation } \\
\text { phase is strongly } \\
\text { encouraged by } \\
\text { the external } \\
\text { implementation } \\
\text { team. }\end{array}$} \\
\hline & $\begin{array}{l}\text { Feedback impacts and } \\
\text { outcomes of the } \\
\text { innovation }\end{array}$ & $\begin{array}{l}\text { Being an end-user can } \\
\text { be inclusive with other } \\
\text { implementation roles }\end{array}$ & & \\
\hline
\end{tabular}

In the Preparation phase the structured implementation team meetings focus on the customization of tools, designing organizationally relevant implementation interventions, establishing timelines, modes/methods of education delivery, and customizations of evaluation measures that are meaningful to the organization and endusers. A collaborative 'readiness for change' assessment and environmental scan begins the Preparation phase. A Strength, Weaknesses, Opportunities and Threats (SWOT) matrix structures the assessment to uncover organization and team-based implementation needs and resources (31). Purposeful pre-emptive review of unique organizational context prior to introducing the innovation with attention to multiple organizational levels and enduser groups is an important part of implementation planning to achieve contextual fit. Frequent checking of individual perceptions increases the validity and utility of this assessment activity.

The local and external teams will set timelines for the progressive implementation phases and build implementation specific communication plans (for example weekly meetings or linking of internal and external communities of practice). The teams collaboratively develop core education materials and practice prompts, and build the safeguards, tools and resources that preserve fidelity of the innovation. Organizationally relevant performance measures are set, (for example, audit and feedback approaches), marketing and dissemination activities are developed and plans for sustainment created during in this phase. These tasks are accomplished through regular and frequent internal and external team meetings accomplish these tasks which focus on plans that complement the local organizational and workforce expertise, existing organizational practices, knowledge and practice culture whist integrating the implementation expertise of the external team.

\section{Introduction Phase}

Organization-level endorsement of the implementation program and foreshadowing of the various associated changes that users will experience, grounds activities in this phase. Gestures of overt support from organizational leadership and selected individual endorsement from influential individuals is an important component of the initial exposure that end users will have to the innovation. The organizational leaders provide this endorsement and that support may take the form of letters, personal participation in implementation activities or securing access to resources. 
Activation of the implementation interventions selected in the Preparation phase is the focus in the Introduction phase. Implementation leadership teams and selected primary implementers (guided by the local implementation team) weigh and select from the implementation interventions and activity within the program and select those of relevance to their practice setting. These interventions can be adapted to achieve local 'fit' and must be compatible with existing process and norms. End-user involvement is recommended, as is attention paid to leveraging established social processes that might support adoption.

In this Introduction tertiary implementation facilitators support awareness and learning about the innovation and implementation activities as well as provide a conduit for feedback about implementation progress, expected and unexpected impacts. Customizations designed in the Preparation phase are now trialed and revised, as needed in an ongoing and reciprocal nature. Recommended introductory implementation interventions and activities include; short loop communication processes, identifying and leveraging social mechanisms of influence within teams and units, thoughtful customization of the innovation and implementation activities. In this phase, implementation interventions, evaluation strategies and facilitated learning processes are incorporated in a progressive and responsive implementation plan. Ongoing, short loop communication enabled by regular, frequent scheduled meetings between stakeholder groups and should continue until implementation is completed.

Local and external teams meet at regular intervals (weekly in the case of BedsidePEWS) for frequent input from end-users, support decisions/revision to the implementation plan; mitigate/manage unintended consequences of the implementation, and to identify emerging challenges related to the progressing implementation. Additional communication via email and as in-person 1:1 conversation is encouraged. For example, ongoing communication between the local educational lead (secondary role) with the external team education expert.

Opportunities to connect end users and implementation leadership with other implementing organizations provide a platform for sharing experiences and solution between sites. The external implementation team can act as a conduit between implementing organizations. Local implementers may reflect, evaluate and articulate their own experiences of the implementation and share their insights as means to support buy-in and extend collective learning for all participating organizations. This phase typically advances to the activation phase at the completion of pilot trials, 'run-in' is completed, when the innovation 'goes live' in the organization or when a critical mass of end users is prepared and expectation for application in practice are introduced.

\section{Activation phase}

The Activation phase focuses on the ongoing assessment of innovation and its impact on organizational and social context. Interventions here could include user level (interviews), team level (case debriefings) system (serial environmental scans) and outcomes measures (quality indicators). These are actioned collaboratively with external content experts and primary and secondary implementers within the organization. The continued customization of the innovation within the established fidelity parameters in this phase involves active solicitation of the preferences of end-users, intentional integration with existing systems and familiar methods of working. Focus is on making the innovation work in the various micro contexts across the organization with attention to supporting technical as well as social integration of the innovation. Secondary, tertiary, and end-user roles maintain vigilance of the required innovation specific behaviours in order to preserve the fixed components of the innovation and continue to guide point of care modification(s) that emerge. This serves to enhance familiarity and fit of the innovation with existing practices, tools and language, and supports local end user 
engagement in process with the goal of maximizing 'fit' within each organization. Open acknowledgment of the tension between fit and fidelity is by implementation leaders, primary and secondary implementations and collaborative navigation of solutions is encouraged in this phase. The external team ensuring the integrity of the innovation actively moderates these activities.

In the Activation phase, end-user feedback processes include formal and informal evaluation of practice behaviours and exploration of the impacts of implementation interventions. Feedback is used to inform ongoing modifications to implementation activities, the innovation itself, the educational programing, materials, practice tools and integration support activities. Specific processes can include audit and feedback, case review, simulation and peer coaching.

Formal enquiry by the external team is standardized and built in as part of regularly scheduled external and local implementation team meetings during this phase. Iterative development of implementation activities or adaptations in the context of real time experiences can surface from these discussions. For example, during BedsidePEWS activation phase, walk-around rounding activities and targeted end-user meetings emerged. Audits of pre-determined innovation-relevant practice behaviours and adherence measures for core innovation actions complement informal practice reviews, and provide opportunities for bidirectional communication about experiences with the innovation and surface emerging challenges. End-user and decision maker surveys and informal interactions with local champions and coaches can inform this assessment in both the activation and later phases. Sharing of the resulting information creates situation awareness, contributes to learning, and facilitates end-user input. Existing organizational performance data can extend and complement active implementation interventions. Scheduling and oversight of education delivery is undertaken at the core primary implementation planners. Interval evaluation of knowledge uptake across the implementation continuum gauge end-user integration of adoption of education and address impacts of learning unlearning strategies.

Strategies to facilitate learning and unlearning selected in the Preparation phase are fit to the learning norms of the professional groups targeted for adoption. Learning strategies must also include plan for those joining the organization during and after the implementation period and re-fresher education/support, and point-of-care education are developed for each organization. Multiple modalities for education and learning support are encouraged. Leveraging social mechanisms for change, for example, collegial competitive reporting (setting organizationally relevant performance goals and contrasting performance between teams/units) can extend the educational activities and support team level change. Strategies offered that are specific to facilitating both new behaviours and unlearning of old practices/behaviours; simulation, case reviews and debriefs, public acknowledgements of leading practices and one-on-one coaching. These same strategies support sustainment of the innovation and mitigate the re-emergence of prior practices.

Sustainment planning includes building and /or activating existing reservoirs of organizational learning to support of ongoing adoption (30). Examples of sustainment interventions include; purposeful sharing of 'good outcomes', case examples of effective application of the innovation, creating platforms for sharing positive experiences, insertion of the innovation into established organizational communication pathways like documentation and quality measures.

\section{Integration phase}


In the Integration phase, the activation activities continue. Roles associated with the implementation are reorganized - revised such that innovation specific responsibilities are taken up as part of existing positions or permanent implementation roles may be created in the organization. For example, innovation adherence surveillance may be led by the hospital quality improvement team or a specific role might be developed to provide oversight of the clinical application of the innovation within units or across the organization. In this phase, primary implementation planners focus on facilitating the integration of the innovation into the organizational reservoirs of knowledge (30). Example of this are the integration of the innovation and associated learning, tools and resources into in the organizations onboarding processes, embedding the innovation into organizational policy and procedure, and incorporation of performance measures associated to the innovation at the patient, team and systems levels as appropriate (30). Ongoing implementation evaluation measures are then modified for ongoing measures of success in the context of the specific innovation. Within this phase is also an opportunity to solidify the social mechanism(s) that supported the implementation for example through formalizing coaching relationships or communities of practice within and between organizations that have adopted the innovation (31). Table 2 outlines the implementation sub goals for each implementation phase 
Table 2

Phases of PRISM and the associated operational goals.

\begin{tabular}{|c|c|c|c|c|}
\hline Phase & Preparation & Introduction & Activation & Integration \\
\hline Foci & $\begin{array}{l}\text { Anticipatory } \\
\text { Planning } \\
\text { Customization }\end{array}$ & $\begin{array}{l}\text { Education } \\
\text { Tool development } \\
\text { Reviewing/adaptation }\end{array}$ & $\begin{array}{l}\text { Innovation } \\
\text { application to } \\
\text { practice } \\
\text { Facilitation of } \\
\text { change } \\
\text { Evaluation/revision }\end{array}$ & $\begin{array}{l}\text { Normalization } \\
\text { Transition } \\
\text { Sustainment }\end{array}$ \\
\hline Goal (s) & $\begin{array}{l}\text { 1] Develop contexted } \\
\text { and responsive } \\
\text { implementation plan } \\
\text { 2] Optimize innovation } \\
\text { fit } \\
\text { 3] Anticipate and } \\
\text { mitigate factors } \\
\text { impacting adoption }\end{array}$ & $\begin{array}{l}\text { 1] introduce } \\
\text { innovation to } \\
\text { stakeholders } \\
\text { 2] Trial } \\
\text { implementation } \\
\text { interventions } \\
\text { 3] Refine fit of } \\
\text { innovation } \\
\text { 4] Refine } \\
\text { implementation plan }\end{array}$ & $\begin{array}{l}\text { 1] Launch } \\
\text { innovation into } \\
\text { practice } \\
\text { 2] Ongoing } \\
\text { evaluation of } \\
\text { impacts } \\
\text { 3] Refine innovation } \\
\text { in relation to context } \\
\text { of use } \\
\text { 4] Secure end-user } \\
\text { buy in }\end{array}$ & $\begin{array}{l}\text { 1] Normalize new } \\
\text { practices/behaviours } \\
\text { 2] Activate } \\
\text { sustainment } \\
\text { interventions } \\
\text { 3] Facilitate } \\
\text { communities of } \\
\text { practice within or } \\
\text { outside of } \\
\text { organization }\end{array}$ \\
\hline $\begin{array}{l}\text { Potential } \\
\text { Activities }\end{array}$ & $\begin{array}{l}\text { Establish local team. } \\
\text { Relationship building } \\
\text { with external } \\
\text { implementation team. } \\
\text { Readiness } \\
\text { assessment. } \\
\text { Environmental scan. } \\
\text { Design } \\
\text { implementation } \\
\text { (timeline, intervention } \\
\text { \& evaluation). } \\
\text { Customization } \\
\text { (innovation, education } \\
\text { and tools). } \\
\text { Develop } \\
\text { communication plan. } \\
\text { Obtain organization } \\
\text { endorsement. } \\
\text { Stakeholder } \\
\text { interviews/canvassing. }\end{array}$ & $\begin{array}{l}\text { Activate } \\
\text { communication plan. } \\
\text { Engage stakeholders. } \\
\text { Refine innovation fit. } \\
\text { Pilot/refine } \\
\text { implementation } \\
\text { interventions. } \\
\text { Provide } \\
\text { education/training. } \\
\text { Launch } \\
\text { marketing/awareness } \\
\text { interventions. }\end{array}$ & $\begin{array}{l}\text { Disseminate new } \\
\text { practice } \\
\text { expectations } \\
\text { associated with the } \\
\text { innovation. } \\
\text { Audit and feedback } \\
\text { to end -users and } \\
\text { decision-makers. } \\
\text { Social and system } \\
\text { reinforcement of } \\
\text { new } \\
\text { practices/behaviors. } \\
\text { Surveillance for and } \\
\text { address } \\
\text { unanticipated } \\
\text { impacts of changes } \\
\text { Continued } \\
\text { refinement of } \\
\text { innovation for fit. } \\
\text { Multi-model } \\
\text { Education/training. }\end{array}$ & $\begin{array}{l}\text { Activate sustainment } \\
\text { plan. } \\
\text { Decrease frequency } \\
\text { of external } \\
\text { consultation. } \\
\text { Review adherence } \\
\text { trends/care impacts- } \\
\text { or other innovation } \\
\text { relevant outcomes. } \\
\text { Integrate ongoing } \\
\text { innovation relevant } \\
\text { outcome measures. } \\
\text { Embed innovation } \\
\text { into existing } \\
\text { routines, } \\
\text { organizational } \\
\text { metrics, roles or } \\
\text { organizational } \\
\text { informational } \\
\text { networks. }\end{array}$ \\
\hline
\end{tabular}

The initial preparation phase is review and planning focused. Objectives are to understand the organizational preferences and resources and anticipate factors that may influence success across the implementationadoption continuum. Activities included formation of the local team; organizational readiness assessment or environmental scan, implementation program design process, customization of tools, education, 
marketing/dissemination strategies, evaluation measures, and sustainment planning. The introduction phase activities aim to maximize stakeholder engagement, share the rationale-for change, new practice expectations deliver end-user education, and to support newly exposed end-users with practice integration strategies. The activation phase marks the launch of the innovation into practice. Goals are to support practice expectations, initiate audit and feedback mechanisms that are linked with responsive modifications based on end user experience and needs and ongoing reinforcement of the protected core elements of the innovation. The integration phase reflects the normalization of the innovation as part of practice. Goals relate to supporting communities of practice, embedding the innovation into administrative and clinical routines, and refinements to and execution of the sustainment plan.

For the BedsidePEWS implementation program timelines were created during the initial planning phase creating a road map that identified explicit milestone dates/intervals, for example, 'go live date(s)'with the innovation. These milestones can be set across an organization or as series of timelines attached to interorganizational units, teams or processes.

\section{Implementation Program Goals:}

We articulated the goals for our implementation approach and then identified core design principles to inform implementation programming. The overarching goals of the implementation program were principle-based and also reflected innovation specific goals. We distilled general priorities for successful implementation to three overarching goals: integrate the innovation into the existing organizational culture and learning/unlearning systems, actively support practice integration (adoption) and allow for iterative feedback across the scope of the implementation. Specifically, for the implementation of BedsidePEWS, we desired a further 4 innovation specific goals; i] ensure technical fidelity of the BedsidePEWS innovation, [ii] embed the pragmatic components of the innovation into routine/normalized practices; [iii] enable ongoing formative and summative assessments of implementation processes - including the level of adoption achieved, sustainability and [iv] inform responses to any threats and opportunities to optimize uptake emerging during implementation.

\section{Results}

\section{Design Principles:}

We applied five theoretical design principles to guide foundational implementation programming and enable a focused and comprehensive approach to implementation planning. Earlier project team experiences implementing organizational level innovations underscored the need for a thoughtful and theoretically consistent approach to integrating a complex innovation into existing systems. The team collaboratively surfaced these principles to ground implementations taking place in acute care hospital setting. Drawing on over 50 years of combined clinical education and practice experience, the project implementation leaders (2), an expert educator (1), and education coordinator (1) explored past implementation challenges and successes and distilled these with the current evidence guiding implementation. The principles included:1] flexibility and responsiveness of implementation actions to organizational context; 2] thoughtful and measured customization of the innovation and implementation tools; 3] optimized end-user engagement; 4] intentional integration with existing organizational process and; 5] leveraging social factors. Each principle is generalizable across complex innovations in hospital settings and allows for fitting programs to innovation specific characteristics. 
Clear linkages between these principles and the innovation specific objectives for implementation were then established. For example, earlier pilots of the BedsidePEWS innovation demonstrated the importance of actively preserving innovation fidelity and the importance of consistent communication between clinical end-users and implementation leaders. The integration of the foundational principles guided the development of implementation activities that addressed these factors specific to BedsidePEWS (32).

\section{[i] Make implementation planning and activities flexible and responsive}

The first design principal of flexible and responsive implementation planning attends directly to the dynamic relationship between the innovation, the organization, and the implementation processes addressed in PRISM (2). The motivation for responsive planning is to improve the 'fit' of the implementation with the local environment facilitating more integrated and organizationally familiar approaches to implementation. This flexibility enables space within the implementation program for 'in process' adaptations and allows for nimble responses to the anticipated and unanticipated real-time impacts of both the innovation and implementation activities.

Responsive facilitation of new practice behaviours and early recognition and management of potential threats to the desired change(s) also enhance process efficiency. Intentionally embedding responsiveness allows implementors to anticipate and monitor for operational signals to adapt implementation activities e.g., aligning timelines with organizational priorities to account for competing projects/demands allows for adaption of the pace of implementation.

In the implementation of BedsidePEWS flexibility and responsiveness were achieved through interval implementation evaluations (weekly to every two weeks), focused routine inquiry to surface anticipated and unanticipated impacts, and short loop responses (weekly) to emerging issues.

\section{[ii] Include customization of the innovation}

The second principle of improving 'fit' of the innovation to context refers to both the intentional and unintentional modification of innovations as described in PRISM (2). Local modification(s), with attention to preserving fidelity, can increase adoption resulting in less innovation erosion and enhanced implementation efficiency (33).

Conversely, more rigid implementation design approaches may result in reduced adoption or alterations in the innovation at the point of delivery in an unregulated way. This may potentially blunt the desired impacts of the change. This design principle was achieved in BedsidePEWS through the early (preparation phase) and careful articulation of aspects of innovation that are determined to be 'core' or 'fixed' and to the identification of other elements that are modifiable to the local context. This in turn guides local implementation leaders to provide the anticipatory and responsive implementation supports needed within a given context or group of end-users.

\section{[iii] Include end-user participation in local customization and adaptions}

The third principle arises from the observation that innovations are significantly shaped by local context and culture and that participatory implementation approaches can enhance individual, team and organizational 'ownership' of the innovation enhancing adoption $(2,34)$. End-user participation in planning and carrying out customization requires end-users to work in a proactive way with the implementing team and to accept ownership of the implementation outcomes. This principle is equally valid in 'top down' leadership driven implementation as well as for grass roots initiatives primarily driven by the end-users themselves. 
In the case of the BedsidePEWS implementation end-user participation was actively solicited in the preparation phase and integrated across the implementation continuum. This occurred through end-user representation at planning meetings, end-user participation in program goal setting, and end-user input on implementation evaluation strategies.

\section{[iv] Integrate implementation with existing team and organizational processes}

The forth principle of leveraging existing team and organizational processes encourage efficiency of the implementation, facilitate 'normalizing' the new activities associated with the innovation, support continuity with existing organizational processes and help increase alignment of the innovation within a given the organization's existing practice culture (30). An operational consequence of this principle is the need to know, understand and access these processes when planning the local implementation activities, measures and materials. Collaborative planning between innovation experts and the local practice experts is an essential element to achieving this principal. Review of existing educational platforms that were leveraged in both the dissemination and sustainment activities in BedsidePEWS is an example of this principle.

\section{[v] Leverage existing social processes to support implementation}

This fifth design principle acknowledges that social processes such as role modelling, opinion leaders and other persons of influence can be powerful catalysts of change(s) or galvanize resistance to the desired change(s) (35). Explicit consideration of supportive social process can strengthen the connections between implementation leaders and end-users, facilitate communication, legitimize the innovation, and assist end-users to 'let go' (unlearning) of existing practices in favour of the new 'preferred' behaviours $(17,36)$. Application of this principle attends to social process that may be working against or eroding adoption of the innovation. Operationalizing this design principle into the implementation plan requires local knowledge of these processes and identification of key individuals as identified by local implementation leaders.

External social process can also be leveraged to facilitate effective implementation. The formation of a broad community of practice linking all implementing organizations involved in the project extended this principle. Establishing peer connections and a platform to explore common goals and challenges related to the innovation supports the integration and normalisation of both the process of implementing and the adoption of the innovation (31). These linkages can happen within and between micro contexts, between organizations or jurisdictions.

In the case of BedsidePEWS, a foundational social program plan was created that included designated role-based expectations that linked implementation goals to teams and to the relational processes for enacting innovation. This included peer coaches supporting clinical application of BedsidePEWS, escalation pathways for communication about experiences using the innovation and to provided feedback on performance.

\section{Implementation Materials:}

Implementation materials consists of a core material set provided to the local team by the external implantation team that can be modified for use across differing organizational contexts. There is also an opportunity to develop new materials as identified by the local implementation teams. For BedsidePEWS the core material set 
included multi model core education content generalised for all end-users, catalogues of training cases, core audit tools, and marketing materials (for users, decision maker, patients/families and general public). Materials required to properly market the innovation along with clinical prompts for use are available for refinement by local teams (for example posters, clipboards, posters, pocket cards). These materials are customizable for delivery in a variety of settings.

Collaborative modifications of core implementation materials fit to local needs is undertaken in the preparation phase by primary implementation team planners in collaboration with secondary implementation operators, tertiary implementation facilitators and end-users of the innovation. Table 3 provides an overview of the BedsidePEWS implementation tools and materials by phase and tool type identifying the elements that are fixed and items that are customizable for the specific organizational context. 
Table 3

Core Implementation Tools and Materials

\begin{tabular}{|c|c|c|c|c|c|}
\hline Tool & Type & Phase(s) & $\begin{array}{l}\text { Target } \\
\text { audience }\end{array}$ & $\begin{array}{l}\text { Fixed } \\
\text { elements }\end{array}$ & $\begin{array}{l}\text { Customizable } \\
\text { elements }\end{array}$ \\
\hline Badge cards & Prompt & $\begin{array}{l}\text { Activation } \\
\text { Integration }\end{array}$ & End-users & $\begin{array}{l}\text { Standardized } \\
\text { content }\end{array}$ & $\begin{array}{l}\text { Language, } \\
\text { formatting, } \\
\text { distribution } \\
\text { methods }\end{array}$ \\
\hline Clip boards & Prompt & $\begin{array}{l}\text { Activation } \\
\text { Integration }\end{array}$ & End-users & $\begin{array}{l}\text { Standardized } \\
\text { content }\end{array}$ & $\begin{array}{l}\text { Language, } \\
\text { formatting, } \\
\text { distribution } \\
\text { methods }\end{array}$ \\
\hline Pocket cards & Prompt & $\begin{array}{l}\text { Activation } \\
\text { Integration }\end{array}$ & End-users & $\begin{array}{l}\text { Standardized } \\
\text { content }\end{array}$ & $\begin{array}{l}\text { Language, } \\
\text { formatting, } \\
\text { distribution } \\
\text { methods }\end{array}$ \\
\hline Rulers & Prompt & $\begin{array}{l}\text { Activation } \\
\text { Integration }\end{array}$ & End-users & $\begin{array}{l}\text { Standardized } \\
\text { content }\end{array}$ & $\begin{array}{l}\text { Language, } \\
\text { formatting, } \\
\text { distribution } \\
\text { methods }\end{array}$ \\
\hline Posters & Prompt & $\begin{array}{l}\text { Activation } \\
\text { Integration }\end{array}$ & $\begin{array}{l}\text { End-users } \\
\text { Clients/family } \\
\text { Public }\end{array}$ & $\begin{array}{l}\text { Standardized } \\
\text { content }\end{array}$ & $\begin{array}{l}\text { Language, } \\
\text { formatting } \\
\text { Location, target } \\
\text { audience }\end{array}$ \\
\hline $\begin{array}{l}\text { Performance } \\
\text { postings }\end{array}$ & Audit/Feedback & $\begin{array}{l}\text { Activation } \\
\text { Integration }\end{array}$ & $\begin{array}{l}\text { End-users } \\
\text { Primary } \\
\text { Secondary } \\
\text { Tertiary }\end{array}$ & $\begin{array}{l}\text { Standardized } \\
\text { content } \\
\text { Innovation } \\
\text { fidelity } \\
\text { measures }\end{array}$ & $\begin{array}{l}\text { Language, } \\
\text { formatting } \\
\text { Posting location, } \\
\text { frequency. scope }\end{array}$ \\
\hline Tip sheet & Education & $\begin{array}{l}\text { Introduction } \\
\text { Activation }\end{array}$ & End-users & $\begin{array}{l}\text { Standardized } \\
\text { content }\end{array}$ & $\begin{array}{l}\text { Language, } \\
\text { formatting, } \\
\text { distribution } \\
\text { methods }\end{array}$ \\
\hline $\begin{array}{l}\text { 'Frequently } \\
\text { asked questions' } \\
\text { sheet }\end{array}$ & Education & $\begin{array}{l}\text { Introduction } \\
\text { Activation } \\
\text { Integration }\end{array}$ & $\begin{array}{l}\text { End-users } \\
\text { Primary } \\
\text { Secondary } \\
\text { Tertiary }\end{array}$ & $\begin{array}{l}\text { Standardized } \\
\text { content }\end{array}$ & $\begin{array}{l}\text { Language, } \\
\text { formatting, } \\
\text { distribution } \\
\text { methods }\end{array}$ \\
\hline Scenario library & Education & $\begin{array}{l}\text { Introduction } \\
\text { Activation } \\
\text { Integration }\end{array}$ & $\begin{array}{l}\text { Primary } \\
\text { Secondary } \\
\text { Tertiary }\end{array}$ & $\begin{array}{l}\text { Content } \\
\text { curated by } \\
\text { external } \\
\text { innovation } \\
\text { experts }\end{array}$ & $\begin{array}{l}\text { Access } \\
\text { Format (online, hard } \\
\text { copy) } \\
\text { *Site teams can } \\
\text { contribute to library }\end{array}$ \\
\hline
\end{tabular}




\begin{tabular}{|c|c|c|c|c|c|}
\hline Tool & Type & Phase(s) & $\begin{array}{l}\text { Target } \\
\text { audience }\end{array}$ & $\begin{array}{l}\text { Fixed } \\
\text { elements }\end{array}$ & $\begin{array}{l}\text { Customizable } \\
\text { elements }\end{array}$ \\
\hline $\begin{array}{l}\text { Innovation } \\
\text { technical } \\
\text { manual }\end{array}$ & Education & $\begin{array}{l}\text { Introduction } \\
\text { Activation } \\
\text { Integration }\end{array}$ & $\begin{array}{l}\text { End-users } \\
\text { Primary } \\
\text { Secondary } \\
\text { Tertiary }\end{array}$ & $\begin{array}{l}\text { Standardized } \\
\text { content }\end{array}$ & $\begin{array}{l}\text { Language, } \\
\text { formatting, } \\
\text { distribution } \\
\text { methods }\end{array}$ \\
\hline $\begin{array}{l}\text { Education } \\
\text { workshops } \\
\text { (curriculum, } \\
\text { slide and } \\
\text { materials) }\end{array}$ & Education & $\begin{array}{l}\text { Introduction } \\
\text { Activation } \\
\text { Integration }\end{array}$ & $\begin{array}{l}\text { End-users } \\
\text { Primary } \\
\text { Secondary } \\
\text { Tertiary }\end{array}$ & $\begin{array}{l}\text { Standardized } \\
\text { content and } \\
\text { learning } \\
\text { outcome } \\
\text { measures }\end{array}$ & $\begin{array}{l}\text { Customized for } \\
\text { learner groups } \\
\text { (discipline, learner } \\
\text { level or interests) } \\
\text { Venue, timing, } \\
\text { modalities, access }\end{array}$ \\
\hline $\begin{array}{l}\text { Simulation } \\
\text { scenarios }\end{array}$ & Education & $\begin{array}{l}\text { Introduction } \\
\text { Activation } \\
\text { Integration }\end{array}$ & $\begin{array}{l}\text { Primary } \\
\text { Secondary } \\
\text { Tertiary }\end{array}$ & $\begin{array}{l}\text { Standardized } \\
\text { content and } \\
\text { learning } \\
\text { outcome } \\
\text { measures }\end{array}$ & $\begin{array}{l}\text { Customized for } \\
\text { learner groups } \\
\text { (discipline, learner } \\
\text { level or interests) } \\
\text { Venue, timing, } \\
\text { methods (i.e. } \\
\text { immersive, high or } \\
\text { low fidelity) } \\
\text { access }\end{array}$ \\
\hline $\begin{array}{l}\text { Web-based } \\
\text { self-directed } \\
\text { learning module }\end{array}$ & Education & $\begin{array}{l}\text { Introduction } \\
\text { Activation } \\
\text { Integration }\end{array}$ & End-users & $\begin{array}{l}\text { Standardized } \\
\text { content }\end{array}$ & $\begin{array}{l}\text { Integrate local } \\
\text { practices/processes } \\
\text { Language, } \\
\text { formatting, } \\
\text { distribution } \\
\text { methods }\end{array}$ \\
\hline Self-test & Education & $\begin{array}{l}\text { Introduction } \\
\text { Activation } \\
\text { Integration }\end{array}$ & End-users & $\begin{array}{l}\text { Standardized } \\
\text { content }\end{array}$ & $\begin{array}{l}\text { Language, } \\
\text { formatting, } \\
\text { distribution } \\
\text { methods }\end{array}$ \\
\hline $\begin{array}{l}\text { Telephone } \\
\text { hot line }\end{array}$ & Education & $\begin{array}{l}\text { Activation } \\
\text { Integration }\end{array}$ & $\begin{array}{l}\text { End-users } \\
\text { Primary } \\
\text { Secondary } \\
\text { Tertiary }\end{array}$ & $\begin{array}{l}\text { Standardized } \\
\text { operational } \\
\text { support }\end{array}$ & $\begin{array}{l}\text { Access } \\
\text { Iterative problem } \\
\text { solving }\end{array}$ \\
\hline Briefing note & Dissemination & $\begin{array}{l}\text { Preparation } \\
\text { Introduction }\end{array}$ & $\begin{array}{l}\text { End-users } \\
\text { Primary } \\
\text { Secondary } \\
\text { Tertiary }\end{array}$ & $\begin{array}{l}\text { Standardized } \\
\text { content }\end{array}$ & $\begin{array}{l}\text { Language, } \\
\text { formatting, } \\
\text { distribution, } \\
\text { methods }\end{array}$ \\
\hline
\end{tabular}




\begin{tabular}{|c|c|c|c|c|c|}
\hline Tool & Type & Phase(s) & $\begin{array}{l}\text { Target } \\
\text { audience }\end{array}$ & $\begin{array}{l}\text { Fixed } \\
\text { elements }\end{array}$ & $\begin{array}{l}\text { Customizable } \\
\text { elements }\end{array}$ \\
\hline \multirow{2}{*}{$\begin{array}{l}\text { Plain language } \\
\text { pamphlet }\end{array}$} & \multirow[t]{2}{*}{ Dissemination } & Preparation & Clients/family & \multirow{2}{*}{$\begin{array}{l}\text { Standardized } \\
\text { content }\end{array}$} & \multirow{2}{*}{$\begin{array}{l}\text { Language, } \\
\text { formatting, } \\
\text { distribution, } \\
\text { methods }\end{array}$} \\
\hline & & Introduction & Public & & \\
\hline \multirow{4}{*}{$\begin{array}{l}\text { Health care } \\
\text { provider } \\
\text { pamphlet }\end{array}$} & \multirow[t]{4}{*}{ Dissemination } & Preparation & End-users & \multirow{4}{*}{$\begin{array}{l}\text { Standardized } \\
\text { content }\end{array}$} & \multirow{4}{*}{$\begin{array}{l}\text { Language, } \\
\text { formatting, } \\
\text { distribution } \\
\text { methods }\end{array}$} \\
\hline & & Introduction & Primary & & \\
\hline & & & Secondary & & \\
\hline & & & Tertiary & & \\
\hline \multirow{4}{*}{$\begin{array}{l}\text { Introductory } \\
\text { letter-health care } \\
\text { providers }\end{array}$} & \multirow[t]{4}{*}{ Dissemination } & & End-users & \multirow{4}{*}{$\begin{array}{l}\text { Foundational } \\
\text { messages }\end{array}$} & \multirow{4}{*}{$\begin{array}{l}\text { Language, } \\
\text { formatting } \\
\text { distribution } \\
\text { methods }\end{array}$} \\
\hline & & Introduction & Primary & & \\
\hline & & & Secondary & & \\
\hline & & & Tertiary & & \\
\hline \multirow{2}{*}{$\begin{array}{l}\text { Introductory } \\
\text { letter-families }\end{array}$} & \multirow[t]{2}{*}{ Dissemination } & Preparation & Clients/family & \multirow{2}{*}{$\begin{array}{l}\text { Foundational } \\
\text { messages }\end{array}$} & \multirow{2}{*}{$\begin{array}{l}\text { Language, } \\
\text { formatting, } \\
\text { distribution } \\
\text { methods }\end{array}$} \\
\hline & & Introduction & Public & & \\
\hline \multirow{4}{*}{$\begin{array}{l}\text { Rounds } \\
\text { presentations }\end{array}$} & Dissemination & Preparation & End-users & \multirow{4}{*}{$\begin{array}{l}\text { Standardized } \\
\text { content }\end{array}$} & \multirow{4}{*}{$\begin{array}{l}\text { Customized for } \\
\text { learner groups } \\
\text { (discipline, learner } \\
\text { level or interests) }\end{array}$} \\
\hline & $\begin{array}{l}\text { Community } \\
\text { building }\end{array}$ & Introduction & Primary & & \\
\hline & & & Secondary & & \\
\hline & & & Tertiary & & \\
\hline \multirow[t]{5}{*}{ Web site } & Education & Preparation & End-users & \multirow{5}{*}{$\begin{array}{l}\text { Standardized } \\
\text { content }\end{array}$} & \multirow[t]{5}{*}{ Access } \\
\hline & \multirow{4}{*}{$\begin{array}{l}\text { Community } \\
\text { building }\end{array}$} & Introduction & Primary & & \\
\hline & & Activation & Secondary & & \\
\hline & & Integration & Tertiary & & \\
\hline & & & Public & & \\
\hline \multirow{5}{*}{$\begin{array}{l}\text { Annual } \\
\text { community of } \\
\text { practice } \\
\text { academic } \\
\text { meetings }\end{array}$} & \multirow{5}{*}{$\begin{array}{l}\text { Community } \\
\text { building }\end{array}$} & Preparation & End-users & & \multirow{5}{*}{$\begin{array}{l}\text { Collaboratively } \\
\text { designed and } \\
\text { delivered by the } \\
\text { community of } \\
\text { practice/ external } \\
\text { experts for the } \\
\text { specific innovation }\end{array}$} \\
\hline & & Introduction & Primary & & \\
\hline & & Activation & Secondary & & \\
\hline & & Integration & Tertiary & & \\
\hline & & & $\begin{array}{l}\text { Health care } \\
\text { community }\end{array}$ & & \\
\hline
\end{tabular}

\section{Implementation Evaluation:}

Implementation evaluation in the Preparation, Introduction, and Activation phases are primary formative with findings directly feeding back into the innovation fit and implementation design. Utilizing short loop formative 
evaluations and vetting of the customized tools/products across the Planning, Introductory and refinement in the Activation phase offers a platform to evaluate innovation fidelity, fit within the micro context across an organization and to fine tune the implementation methods themselves. This may include measures of implementation team functioning, post education feedback activities, end user perceptions of the quality of their preparation, utility and adherence with innovation associated behaviors and practices.

In the case of BedsidePEWS, end user adherence to the requisite practice behaviours, audited every week to two weeks, were discussed /addressed at routine implementation meetings. This adherence data along with clinical event based case reviews and secondary implementation role observations is used to generate recommendations that inform ongoing revision and refinement of the implementation plan.

In the final Integration phase, evaluation activities are summative. Findings here informed the innovation specific patient, team and system level impacts as well as the outcomes of the implementation activities. Measuring these impacts complements and extends the earlier assessments of fidelity and are important to inform future implementation projects or further extension of the innovation. Table 4 outlines the evaluation approaches and examples of potential evaluation questions associated with each of the PRISM phases. 
Table 4

PRISM Evaluation Approaches

\begin{tabular}{|c|c|c|c|c|}
\hline Phase & Planning & Introduction & Activation & Integration \\
\hline \multirow{2}{*}{$\begin{array}{l}\text { Evaluation } \\
\text { Approach }\end{array}$} & Anticipatory & Formative & Formative & Summative \\
\hline & Formative & & & $\begin{array}{l}\text { Monitoring } \\
\text { sustainment }\end{array}$ \\
\hline \multirow[t]{5}{*}{$\begin{array}{l}\text { Evaluation } \\
\text { Domains }\end{array}$} & & $\begin{array}{l}\text { Customizations/refinements } \\
\text { of tools/marketing/prompt }\end{array}$ & $\begin{array}{l}\text { Refinements of } \\
\text { innovation }\end{array}$ & \\
\hline & Value & & & Quality \\
\hline & Needs-assessment & $\begin{array}{l}\text { Education } \\
\text { outcomes/preparation }\end{array}$ & $\begin{array}{l}\text { Impact on } \\
\text { stakeholders }\end{array}$ & Consistency \\
\hline & Resource review & Awareness & $\begin{array}{l}\text { Unexpected } \\
\text { outcomes }\end{array}$ & \\
\hline & & & $\begin{array}{l}\text { Innovation } \\
\text { associated } \\
\text { outcomes }\end{array}$ & \\
\hline Organization & Structures & Processes & Processes & $\begin{array}{l}\text { Outcomes } \\
\text { (patient }\end{array}$ \\
\hline Level* & & & Impacts & $\begin{array}{l}\text { system, } \\
\text { organizational }\end{array}$ \\
\hline Implementation & Trial and test & Reaction & Reaction & Transfer \\
\hline$\underset{\star \star}{\text { Processes level }}$ & & Learning & $\begin{array}{l}\text { Learning } \\
\text { Transfer }\end{array}$ & $\begin{array}{l}\text { Results } \\
\text { (individual, } \\
\text { team) }\end{array}$ \\
\hline
\end{tabular}

* Organizational level evaluation approach was informed by Donabedian's Model of Health Care Quality (37).

** Implementation process level evaluation approach was informed by Kirkpatrick's Levels of evaluation (38) 


\begin{tabular}{|c|c|c|c|c|}
\hline Phase & Planning & Introduction & Activation & Integration \\
\hline $\begin{array}{l}\text { Potential } \\
\text { Evaluation } \\
\text { questions }\end{array}$ & $\begin{array}{l}\text { What factors may } \\
\text { influence } \\
\text { implementation } \\
\text { success? } \\
\text { What resources } \\
\text { (structural, human, } \\
\text { monetary, } \\
\text { operational, time...) } \\
\text { are needed? } \\
\text { Will the innovation } \\
\text { 'fit' the targeted } \\
\text { setting(s)? } \\
\text { What needs can we } \\
\text { anticipate and } \\
\text { address? }\end{array}$ & $\begin{array}{l}\text { Are end users prepared to } \\
\text { use the innovation? } \\
\text { Is awareness adequate } \\
\text { across the organization? } \\
\text { Are all stakeholders } \\
\text { heard/represented in } \\
\text { process? } \\
\text { Does the innovation } \\
\text { function as anticipated? } \\
\text { What is the impact of } \\
\text { implementation tools, } \\
\text { resources and activities? } \\
\text { What factors might be } \\
\text { inhibiting or facilitating } \\
\text { uptake of new behaviors or } \\
\text { practices } \\
\text { Are there adequate support } \\
\text { to unlearn old practices? } \\
\text { What are the } \\
\text { motivations/tone of the } \\
\text { change? }\end{array}$ & $\begin{array}{l}\text { Is the } \\
\text { innovation } \\
\text { achieve desired } \\
\text { impacts? } \\
\text { Are there areas } \\
\text { that require } \\
\text { focused } \\
\text { implementation } \\
\text { efforts? } \\
\text { What are the } \\
\text { adherence } \\
\text { levels? } \\
\text { Is fidelity of the } \\
\text { innovation } \\
\text { preserved? }\end{array}$ & $\begin{array}{l}\text { What are the } \\
\text { unanticipated } \\
\text { impacts of the } \\
\text { change? } \\
\text { Are there } \\
\text { threats to } \\
\text { sustainment? } \\
\text { Has the } \\
\text { innovation } \\
\text { penetrated the } \\
\text { knowledge } \\
\text { reservoirs of } \\
\text { the } \\
\text { organization? } \\
\text { What is the } \\
\text { extent of } \\
\text { adoption of } \\
\text { the } \\
\text { innovation? }\end{array}$ \\
\hline
\end{tabular}

\section{Discussion}

Five key lessons emerged from our experience with the implementation of BedsidePEWS that can guide future use of this implementation design and the approach that we describe here.

Lesson 1: Grounding Implementation Approach in Theory Assists Conceptually \& Practically. First, this report of a theoretically grounded implementation approach for a single complex innovation spanning multiple diverse hospital organizations creates a conceptual and practical framework that may be applied for other complex healthcare innovations. The generation of foundational design principles and the PRISM conceptual framework informed the planning and application of innovation-specific implementation processes and actions. The overarching objectives for BedsidePEWS implementation are consistent with objectives for most healthcare innovations thus allowing for to potential application to other innovations and implementation programs.

The use of a theoretical framework enabled explicit description and planned evaluation of individual and cumulative implementation interventions. Through explicit mapping of implementation interventions to their goals and a thoughtful evaluation of desired and unexpected outcomes, informed adaptations to the implementation and served to prevent unnecessary duplication of less effective implementation strategies in each setting. This also enables capacity building related to implementation within the individual organizations as well as between organizations. 
Lesson2: A Concerted, Phased Approach to Implementation Offers Several Advantages.

Second, we describe the potential advantages of phased approaches in development and operationalization of implementation programing. The four phases of PRISM applied in the design are described for in ways that permit application in implementation programming for other complex innovations. Phased implementation approaches enabled: 1] the ability to 'pilot' test the innovation in-situ, which may permit identification and modification of factors impacting the innovation's introduction and fit, and to address any unexpected impacts on other organizational activities; 2] the ability to tailor implementation activities to specific learning and timelines for various user groups; 3] may assist in pacing the implementation to align with organizational goals and priorities; 4] enables strategic leveraging of facilitative relationships between units within and between organizations, including competitive motivations, role modeling or building connected communities of practice focused on the innovation, 5] allows for reflexivity, early recognition and revision of activities that are not meeting needs or are contributing to fidelity/erosion issues, 6] is a preemptive way to mitigate complexity of the innovation and the environment to which is it being applied.

Lesson 3: Concerted Consideration of Innovation "Fit" Can Improve Implementation Processes. Third, this report describes the pragmatic application of a flexible approach during the implementation-adoption continuum to increase fit of the innovation and implementation programing to the specific setting. The design of the flexible core materials and philosophy of enable modification preserving essential innovation specific elements is central to the success of complex innovations. Customizable implementation planning allows for attention to micro cultures and flexibility of the tools and implementation interventions (for example audit and feedback approaches) maximizes existing resources and plays to the strengths across as well as between teams (competitive approaches to motivate integration and consolidation)

Lesson 4: Consider Sustainment Concurrent with Implementation.

Fourth, the approach addresses sustainment of the innovation, including flexibility to fit standardized implementation interventions like education, marketing, communication, audit and feedback and end-user engagement necessary for compatibility of an innovation across a hospital system. Intentional sustainment planning across the implementation phases ensures the penetration of organizationally relevant reservoirs of organizational learning and thus sustained adoption of the newly adopted innovation. Attention to sustaining the innovation at the individual and organizational level learning are both important for ongoing adoption and normalization of the innovation into routine practice. Approaches to achieve this vary between implementing teams, disciplines and organizations and local as well as external implementation expertise are crucial to uncover and leverage these strengths.

Lesson 5: End-User Engagement Benefits Planning \& Operationalization.

Lastly, embracing end-user participation in implementation planning and operationalization across the continuum of innovation adoption approach enhances transparency of process and strengthens organizational level problem- solving formatively across implementation periods.

\section{Limitations}


There are limitations to the generalizability and representativeness of the approaches described in this paper. Our approach is dependent upon revising for 'fit' on a continual basis. This requires the time and expertise of local experts who are assumed to know or have access to knowledge of local culture, learning reservoirs and organizational resources. Mis-information about these elements may undermine the success of implementation programming and efforts.

This implementation approach requires high levels of organizational attention and support, including allocation of discretionary organizational resources (tangible and human). which may not be feasible in some settings. Without this level of support, innovations may be vulnerable to competition from other organizational priorities and/or the demands on implementation leaders assigned to other roles and duties. A balanced approach is required in terms of engagement of leadership, frontline, education specialists and research/quality improvement expertise.

Our conceptually grounded description of implementation program design is untested beyond the BedsidePEWS project. Attention was paid to implementation approaches that preserve the integrity of the innovation as the customization process can risk dilution of the innovation benefits unless carefully curated and evaluated across the implementation process. This approach may not be transferable to other innovations or settings.

Evidence of the effectiveness of this administered program is predominantly indirect. Our randomized trial of this innovation's impact (BedsidePEWS) found improved processes and timeliness of care but did not achieve the innovation's primary measure of 'success' related to patient outcomes (39). Evaluation of the relationships between the nature of implementation and extent of adoption will provide additional evidence about the overall effectiveness of the approach used to develop a customizable implementation program for use in a diverse range of hospitals. Furthermore, application of this approach to other complex healthcare innovations will provide additional evidence of the validity and utility of this design.

\section{Conclusions}

Successful adoption and sustainment of an innovation in the context of complex health care organizations requires behavioral, conceptual, and cultural changes for the participating providers, teams and organizations $(41,42)$. Therefore, implementation design must address the skills and pragmatic requirements for using the innovation as well as the relational and contextual issues that influence change in healthcare settings (43). We believe that describing implementation strategies for complex healthcare interventions should be routine and a part of effective knowledge translation practices.

We have illustrated that theoretically grounded and locally contexted implementation approaches are feasible for the adoption and integration of complex hospital wide innovations. Implementation approaches differ between organizations and within organizations, one size does not fit all. Creation of implementation programs based on considered design principles, integrating implementation knowledge leaders, engaging local organizational and practice experts are a key precursor to innovation adoption. Attention to the fitting of an innovation to local practices, the setting, organizational culture and end-user preferences can be achieved while maintaining the fidelity of the innovation. Future implementation research should prospectively explore innovation fidelity and process of sustainment emerging from implementation activities and sustainment measures. Articulation of detailed description of the implementation strategies for complex healthcare interventions are foundational for effective knowledge translation and enduring change.

Page 23/27 


\section{Declarations}

Ethics approval: not applicable

Consent for publication: not applicable

Availability of data and materials: All data generated or analysed during this study are included in this published article.

Competing interests: The authors declare that they have no competing interests.

Funding: This work is unfunded.

Authors contributions: KDP was the major contributor to developing the manuscript. WB and CP contributed substantive editorial revisions. All authors read and approved the final manuscript.

Acknowledgements: none

\section{References}

1. Cummings GG, Estabrooks CA, Midodzi WK, Wallin L, Hayduk L. Influence of organizational characteristics and context on research utilization. Nursing research. 2007 Jul 1;56(4):S24-39.

2. Dryden-Palmer KD, Parshuram CS, Berta WB. Context, complexity and process in the implementation of evidence-based innovation: a realist informed review. BMC Health Services Research. 2020;20(1).

3. Graham ID, Logan J, Harrison MB, Straus SE, Tetroe J, Caswell W, et al. Lost in knowledge translation: time for a map? The Journal of continuing education in the health professions. 2 006;26(1):13-24.

4. Greenhalgh T, Papoutsi C. Spreading and scaling up innovation and improvement. Bmj. 2019:I2068.

5. Canadian Institutes of Health Research. Quarterly Financial Report for the Quarter Ended June 30, [internet]. 2021[cited 2022 Jan10]. Available from https://cihr-irsc.gc.ca/e/52640.html

6. Damschroder LJ, Aron DC, Keith RE, Kirsh SR, Alexander JA, Lowery JC. Fostering implementation of health services research findings into practice: a consolidated framework for advancing implementation science. Implementation Science. 2009;4(1).

7. Estabrooks CA. Prologue: A program of research in knowledge translation. Nursing Research. $2007 \mathrm{Jul}$ 1;56(4):S4-6.

8. Reimer-Kirkham S, Varcoe C, Browne AJ, Lynam MJ, Khan KB, McDonald H. Critical inquiry and knowledge translation: exploring compatibilities and tensions. Nursing Philosophy. 2009 Jul;10(3):152-66

9. Rycroft-Malone J. Theory and knowledge translation: setting some coordinates. Nursing research. $2007 \mathrm{Jul}$ 1;56(4):S78-85

10. Denis JL, Hébert Y, Langley A, Lozeau D, Trottier LH. Explaining diffusion patterns for complex health care innovations. Health care management review. 2002 Jul 1;27(3):60-73.

11. Dobbins M, Ciliska D, Cockerill R, Barnsley J, DiCenso A. A framework for the dissemination and utilization of research for health-care policy and practice. Worldviews on Evidence-based Nursing presents the archives of Online Journal of Knowledge Synthesis for Nursing. 2002 Mar;9(1):149-60. 
12. Ferlie E, Wood M, Fitzgerald L. Some limits to evidence-based medicine: a case study from elective orthopaedics. BMJ Quality \& Safety. 1999 Jun 1;8(2):99-107.

13. Gagnon M-P, Labarthe J, Légaré F, Ouimet M, Estabrooks CA, Roch G, et al. Measuring organizational readiness for knowledge translation in chronic care. Implementation Science. 2011;6(1).

14. McCormack B, Kitson A, Harvey G, Rycroft-Malone J, Titchen A, Seers K. Getting evidence into practice: the meaning ofcontext'. Journal of advanced nursing. 2002 Apr;38(1):94-104.

15. Novotná G, Dobbins M, Henderson J. Institutionalization of evidence-informed practices in healthcare settings. Implementation Science. 2012 Dec;7(1):1-8.

16. Petticrew M, Anderson L, Elder R, Grimshaw J, Hopkins D, Hahn R, et al. Complex interventions and their implications for systematic reviews: a pragmatic approach. Journal of clinical epidemiology. 2013;66(11):1209-14.

17. Sharma N, Herrnschmidt J, Claes V, Bachnick S, De Geest S, Simon M. Organizational readiness for implementing change in acute care hospitals: An analysis of a cross-sectional, multicentre study. Journal of Advanced Nursing. 2018;74(12):2798-808.

18. Gadomski AM, Brower M, Gadomski AM. Bronchodilators for bronchiolitis. 2010.

19. Parshuram CS, Duncan HP, Joffe AR, Farrell CA, Lacroix JR, Middaugh KL, Hutchison JS, Wensley D, Blanchard N, Beyene J, Parkin PC. Multicentre validation of the bedside paediatric early warning system score: a severity of illness score to detect evolving critical illness in hospitalised children. Critical Care. 2011 Aug;15(4):1-1.

20. Berta W, Teare GF, Gilbart E, Ginsburg LS, Lemieux-Charles L, Davis D, Rappolt S. Spanning the know-do gap: understanding knowledge application and capacity in long-term care homes. Social science \& medicine. 2010 May 1;70(9):1326-34.

21. Rycroft-Malone J, Wilkinson JE, Burton CR, Andrews G, Ariss S, Baker R, et al. Implementing health research through academic and clinical partnerships: a realistic evaluation of the Collaborations for Leadership in Applied Health Research and Care (CLAHRC). Implement Sci. 2011;6:74.

22. Retsas A. Barriers to using research evidence in nursing practice. Journal of advanced nursing. 2000 Mar;31(3):599-606.

23. Rogers E.. Diffusion of Innovations 5th ed. New York Free Press; 2003.

24. Gagliardi AR, Brouwers MC, Palda VA, Lemieux-Charles L, Grimshaw JM. How can we improve guideline use? A conceptual framework of implementability. Implement Sci. 2011;6:26.

25. Kitson AL. The need for systems change: reflections on knowledge translation and organizational change. Journal of Advanced Nursing. 2009;65(1):217-28.

26. Harvey G, Kitson A. PARIHS revisited: from heuristic to integrated framework for the successful implementation of knowledge into practice. Implementation Science. 2016;11(1).

27. Estabrooks CA, Thompson DS, Lovely JJ, Hofmeyer A. A guide to knowledge translation theory. The Journal of continuing education in the health professions. 2006;26(1):25-36.

28. Berta W, Teare GF, Gilbart E, Ginsburg LS, Lemieux-Charles L, Davis D, Rappolt S. Spanning the know-do gap: understanding knowledge application and capacity in long-term care homes. Social science \& medicine. 2010 May 1;70(9):1326-34. 
29. Argote L, Ingram P, Levine JM, Moreland RL. Knowledge Transfer in Organizations: Learning from the Experience of Others. Organizational Behavior and Human Decision Processes. 2000;82(1):1-8.

30. Virani T, Lemieux-Charles L, Davis DA, Berta W. Sustaining change: once evidence-based practices are transferred, what then?. Healthcare quarterly (Toronto, Ont.). 2009 Jan 1;12(1):89-96.

31. Humphrey AS. SWOT analysis. Long Range Planning. 2005;30(1):46-52.

32. Cundill G, Roux DJ, Parker JN. Nurturing communities of practice for transdisciplinary research. Ecology and Society. 2015;20(2).

33. Parshuram CS, Bayliss A, Reimer J, Middaugh K, Blanchard N. Implementing the Bedside Paediatric Early Warning System in a community hospital: A prospective observational study. Paediatrics \& child health. 2011 Mar 1;16(3):e18-22.

34. Carroll JC, Wilson BJ, Allanson J, Grimshaw J, Blaine SM, Meschino WS, et al. GenetiKit: a randomized controlled trial to enhance delivery of genetics services by family physicians. Family practice. 2011;28(6):615-23.

35. Rycroft-Malone J. The PARIHS framework-a framework for guiding the implementation of evidence-based practice. Journal of nursing care quality. 2004 Oct 1;19(4):297-304.

36. Fineout-Overholt E, Levin RF, Melnyk BM. Strategies for advancing evidence-based practice in clinical settings. JNY State Nurses Assoc. 2004 Sep 1;35(2):28-32.

37. Lukas CV, Mohr DC, Meterko M. Team effectiveness and organizational context in the implementation of a clinical innovation. Quality Management in Healthcare. 2009 Jan 1;18(1):25-39.

38. Donabedian A. Evaluating the quality of medical care. The Milbank memorial fund quarterly. 1966 Jul 1;44(3):166-206.

39. Reio TG, Rocco TS, Smith DH, Chang E. A critique of Kirkpatrick's evaluation model. New Horizons in Adult Education and Human Resource Development. 2017 Apr;29(2):35-53.

40. Parshuram CS, Dryden-Palmer K, Farrell C, Gottesman R, Gray M, Hutchison JS, et al. Effect of a Pediatric Early Warning System on All-Cause Mortality in Hospitalized Pediatric Patients. Jama. 2018;319(10):1002.

41. Hawe P, Shiell A, Riley T. Theorising interventions as events in systems. American journal of community psychology. 2009;43(3-4):267-76.

42. Rogers PJ. Using Programme Theory to Evaluate Complicated and Complex Aspects of Interventions. Evaluation. 2008;14(1):29-48.

43. Sterman JD. Learning from evidence in a complex world. American journal of public health. 2006;96(3):50514.

\section{Figures}




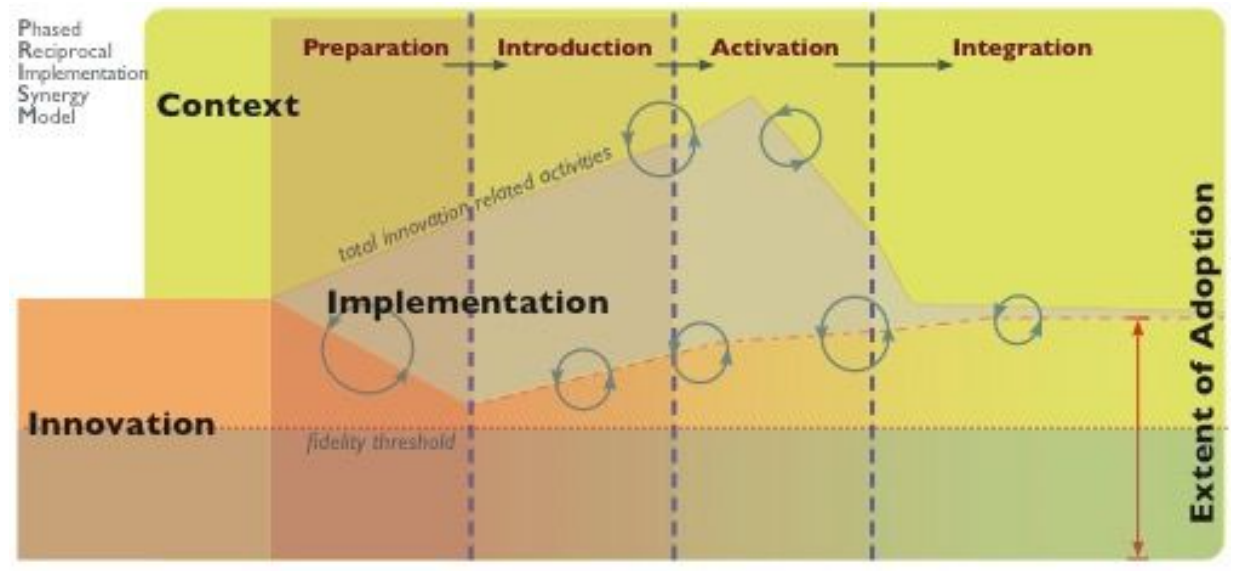

\section{Figure 1}

The Phased Reciprocal Implementation Synergy Model (PRISM)

The Phased Reciprocal Implementation Synergy Model (PRISM) represents the introduction of an innovation into a healthcare context. The innovation is moved through phases of preparation, introduction, activation and integration. Reciprocal interactions between innovation, implementation and context are represented by the circles with arrows. During implementation synergistic adaptations occur and are facilitated as implementers and end-users in the context refine and ' $\mathrm{fit}$ ' the innovation and the implementation processes to better match local practices; and as those in the context are in turn influenced by intended and unintended effects of implementation processes and the innovation itself to help match the intent of the innovation. In the integration phase implementation activities become part of routines of the context - specifically maintenance education for existing staff and introduction to practice for new staff. The innovation becomes a part of the context. The outcome of implementation is the extent of adoption - represented on the vertical axis. Below the fidelity threshold of the innovation (dashed red line), the application of the innovation is limited and is no longer linked to beneficial effects indicated in the underpinning research. Extent of adoption falling above the fidelity threshold is linked to innovation uptake as intended with the potential for extensions of the innovation to new domains or areas of practice. 